\title{
FAKTOR FAKTOR PENYEBAB TURUNNYA GROWTH ECONOMIC KAWASAN FTZ DI KEPULAUAN RIAU
}

\author{
Syarif Hidayah Lubis ${ }^{1)}$, Agus Defri Yando ${ }^{2)}$ \\ Universitas Putera Batam, Kota Batam \\ Email: hidayahsyarif@gmail.com ${ }^{1)}$, \\ aguspeace89@gmail.com ${ }^{2}$
}

\begin{abstract}
Keywords: Abstrak
Tourism, MSMEs, PMA; Export, Inflation,

Of the 4 regions of the Free Trade Zone (FTZ) in Indonesia, Riau Islands has 3 regions, namely Batam, Bintan and Karimun, however, in GRDP the last 5 years the FTZ area has experienced less optimal economic growth or is experiencing a decline. Overall economic growth in the Riau Islands FTZ region During the last 6 years there has been a cumulative 6-year decline, namely Batam city at -0.476, Bintan -0.18 Karimun regency at -0.172 . There are several drivers of economic growth in the FTZ region including tourism, MSMEs and inflation. The purpose of this study was to find out the variables that influence the decline in the Economic Growth / GRDP of the FTZ region in the Riau Islands Province. This study uses quantitative research by obtaining secondary data and the techniques used in collecting data are by documentation techniques, namely recording and copying of secondary data. The simultaneous results of the variables of Tourism, MSME and inflation have an effect on the Economic Growth / GRDP, simultaneously the variables of Tourism, MSMEs and inflation have an effect on Economic Growth / GRDP. Partially the tourism / tourist variables have a negative influence on economic growth / GDP. This can be seen tcount (-3.503) <ttable (1.67356) significant value (0.001) $<(0.05)$, MSME variables have a positive effect on Economic Growth $/$ GRDP with tcount (2.841)> t table (1.67356) and significant value (0.016) <(0.05). PMA has no effect on Economic Growth / GRDP. This can be seen with the value of tcount (1.535) <ttable (1.67356)) and significant value (0.131)> (0.05), Exports have an effect on Economic Growth / GRDP with tcount (1.803)> ttable (1.67356) and significant value (0.047) <(0.05), Inflation has an effect on Economic Growth / GRDP with tcount $(0.439)<t$ table (1.67356) and significant value $(0.662)>(0.05)$.
\end{abstract}




\section{Kata Kunci : Abstrak}

Pariwisata, UMKM, Dari 4 daerah kawasan Free Trade Zone (FTZ)di Indonesia Kepulauan PMA, Ekspor, Inflasi, Riau memiliki 3 kawasan yaitu Batam, Bintan dan Karimun namun, PDRB dalam 5 tahun terakhir kawasan FTZ ini mengalami pertumbuhan ekonomi yang kurang optimal atau sedang mengalami penurunan. Pertumbuhan ekonomi secara keseluruhan di kawasan FTZ Kepulauan Riau Selama 6 tahun terakhir mengalami penurunan secara kumulatif 6 tahun yakni kota Batam sebesar -0.476, Kabupaten Bintan -0.18 kabupaten Karimun sebesar -0.172. Ada beberapa penggerak pertumbuhan ekonomi di kawasan FTZ diantaranya adalah pariwisata, UMKM dan Inflasi. Tujuan penelitian ini adalah untuk mengetahui variabel yang berpengaruh terhadap turunnya Pertumbuhan ekonomi/PDRB kawasan FTZ di Provinsi Kepulauan Riau. Penelitian ini menggunakan Teknik kuantitatif dengan memperoleh data sekunder yang telah disediakan dengan cara mendokumentasikan melalui pencatatan dan pengkopian data sumber. Hasil penelitian secara simultan menunjukkan variabel sektor Pariwisata, UMKM dan inflasi memiliki hubungan berpengaruh terhadap Pertumbuhan Ekonomi/PDRB, Secara Parsial variabel sektor pariwisata/wisman Pariwisata/Wisman tidak berpengaruh positif dan signifikan terhadap pertumbuhan ekonomi/PDRB hal ini dapat dilihat thitung ($3,503)<$ ttabel $(1,67356)$, variabel UMKM berpengaruh positif terhadap Pertumbuhan Ekonomi/PDRB dengan Nilai thitung $(2,841)>$ ttabel $(1,67356)$, PMA tidak berpengaruh positif dan signifikan terhadap Pertumbuhan Ekonomi/PDRB hal ini dapat dilihat dengan nilai Nilai thitung $(1,535)<$ ttabel $(1,67356))$, Ekspor berpengaruh positif dan signifikan terhadap Pertumbuhan Ekonomi/PDRB dengan Nilai thitung $(1,803)>$ ttabel $(1,67356)$, Inflasi tidak berpengaruh negatif terhadap Pertumbuhan Ekonomi/PDRB dengan Nilai thitung $(0,439)<$ ttabel $(1,67356)$. 


\section{PENDAHULUAN}

\section{Pendahuluan}

UU No. 36 tahun 2000 tentang kawasan perdagangan bebas dan pelabuhan bebas menyebutkan bahwa kawasan perdagangan bebas dan pelabuhan bebas dapat mendorong kegiatan lalu lintas perdagangan internasional yang mendatangkan devisa bagi negara serta dapat memberi pengaruh dan manfaat besar bagi kesejahteraan masyarakat Indonesia. Kepulauan Riau memiliki 3 kawasan Free Trade Zone (FTZ) yaitu Kota Batam, Kabupaten Bintan dan Kabupaten Karimun namun, dalam 6 tahun terakhir kawasan ini mengalami permasalahan yang sangat serius yakni pertumbuhan ekonomi yang mengalami penurunan secara terus menerus.

Pertumbuhan ekonomi di kawasan FTZ provinsi Kepualauan Riau mengalami penurunan secara kumulatif dalam kurun waktu selama 6 tahun dapat dilihat dalam tabel 1 berikut ini:

Tabel 1. Pertumbuhan ekonomi wilayah FTZ Di Kepri

\begin{tabular}{|c|c|c|}
\hline No & Daerah & Pertumbuhan Ekonomi \\
\hline 1 & Batam & $-0,476 \%$ \\
\hline 2 & Bintan & $-0,18 \%$ \\
\hline 3 & Karimun & $-0,172 \%$ \\
\hline
\end{tabular}
terus menurus tanpa dilakukan perbaikan sektor yang mempengaruhi pertumbuhan ekonomi akan menjadi masalah terhadap roda perekonomian masyarakat terlebih khusus pada masyarakat di kawasan tersebut.

Laju pertumbuhan ekonomi merupakan ukuran keberhasilan atau tidaknya pembangunan ekonomi baik secara nasional ataupun secara regional. Pada umumnya, laju pertumbuhan ekonomi merupakan kenaikan output agregat atas keseluruhan barang dan jasa yang dihasilkan dalam wilayah oleh adanya aktifitas atau kegiatan perekonomian atau Produk Domestik Bruto (PDB). PDB merupakan ukuran umum yang digunakan untuk melihat pertumbuhan ekonomi secara nasional sedangkan PDRB (Produk Domestik Regional Bruto) dijadikan sebagai ukuran untuk mengukur suatu pertumbuhan/perkembangan ekonomi di suatu daerah baik provinsi ataupun kabupaten/kota. Ada beberapa instrument penggerak pertumbuhan ekonomi yang paling mencolok daerah diantaranya adalah pariwisata, UMKM, PMA , Ekspor dan Inflasi.

Atas dasar permasalahan yang sangat urgensi tersebut yang apabila pertumbuhan ekonomi dibiarkan secara terus menerus mengalami penurunan tanpa mencari apa penyebabnya maka hal tersebut akan berdampak negatif kepada masyarakat setempat dan secara umum akan berdampak juga pada pertumbuhan ekonomi secara nasional. Maka peneliti tertarik membuat penelitian dengan judul

"Faktor-Faktor Penyebab Turunnya Growth Economic Kawasan FTZ Di Kepulauan Riau". Dengan tujuan agar faktor penyebab turunnya pertumbuhan ini di ketahui dan dilakukan perbaikan oleh pemerintah terkait.

\section{Telaah Pustaka}

\section{Pariwisata}

Undang-undang No. 10 tahun 2009 tentang kepariwisataan menyebutkan pengertian pariwisata sebagai berikut "Pariwisata adalah berbagai macam kegiatan wisata dan didukung berbagai fasilitas serta layanan yang disediakan oleh masyarakat, pengusaha, Pemerintah, dan Pemerintah Daerah." Sementara objek dari pendapatan pariwisata adalah wisatawan. Dalam undang-undang tersebut menyebutkan definisi wisatawan adalah orang yang 
No. 10 tahun 2009 tentang kepariwisataan menyebutkan bahwa "Kepariwisataan berfungsi memenuhi kebutuhan jasmani, rohani, dan intelektual setiap wisatawan dengan rekreasi dan perjalanan serta meningkatkan pendapatan negara untuk mewujudkan kesejahteraan rakyat".

Sektor kepariwisata memiliki andil yang sangat penting terhadap perekonomian baik itu secara nasional maupun regional, dari sektor kepariwisataan ini dapat menciptakan beberapa manfaat bagi masyarakat yakni bertambahnya lapangan pekerja, rmeningkatnya retistribusi pendapatan, serta semakin kuatnya neraca pembayaran. Salah satu alternatif belanja turis selain melakukan ekspor barang ke luar negeri secara langsung yaitu dengan adanya belanja yang dilakukan para turis atau wisataan hal ini akan memberikan kontribusi yang bermanfaat bagi penerimaan devisa (neraca pembayaran).

Penerimaan devisa dari sektor pariwisata juga dapat dimanfaatkan dalam hal untuk mengimpor barang-barang modal sehingga menghasilkan barang-barang dan jasa, yang pada akhirnya memiliki andil yang baik dalam pertumbuhan ekonomi (Nizar, 2015). (Nizar, 2015) mengembangkan sebuah model pertumbuhan ekonomi dengan memasukkan sektor pariwisata sebagai komponen tambahan untuk permintaan agregat domestik. Hasilnya, sector pariwisata memiliki dampak positif terhadap pertumbuhan ekonomi secara jangka panjang. Penelitian terdahulu yang dilakukan oleh (Nizar, 2015)yang mengungkapkan bahwa pariwisata berpengaruh terhadap pertumbuhan ekonomi di Indonesia. Atas dasar argumen teori dan penelitian terdahulu maka peneliti mengambil hipotesis sementara yakni :

berpengaruh positif dan signifikan terhadap Pertumbuhan Ekonomi/PDRB.

\section{UMKM}

Undang-undang Nomor 20 Tahun 2008 tentang usaha mikro, kecil dan menengah menyebutkan definisi UMK sebagai berikut:

\section{Usaha Mikro}

Usaha Mikro adalah usaha produktif milik orang perorangan dan/atau badan usaha perorangan yang memenuhi kriteria Usaha Mikro yang memiliki kekayaan bersih paling banyak Rp50.000.000 tidak termasuk tanah dan bangunan tempat usaha; atau memiliki hasil penjualan tahunan paling banyak Rp300.000.000

\section{Usaha Kecil}

Usaha Kecil adalah usaha ekonomi produktif yang berdiri sendiri, yang dilakukan oleh orang perorangan atau badan usaha yang bukan merupakan anak perusahaan atau bukan cabang perusahaan yang dimiliki, dikuasai, atau menjadi bagian baik langsung maupun tidak langsung dari Usaha Menengah atau Usaha Besar yang memenuhi kriteria Usaha Kecil langsung maupun tidak langsung dari Usaha Menengah atau Usaha Besar yang memenuhi kriteria Usaha Kecil. Lebih jauh dalam undang-undang tersebut yang menjadi kriteri usaha kecil adalah Kriteria Usaha Kecil adalah sebagai berikut:

a. Memiliki kekayaan bersih lebih dari Rp50.000.000 sampai dengan paling banyak Rp500.000.000 tidak termasuk tanah dan bangunan tempat usaha; atau

b. Memiliki hasil penjualan tahunan lebih dari Rp300.000.000 sampai dengan paling banyak Rp2.500.000.000. 
Usaha Mikro Kecil (UMK) memiliki andil dalam pertumbuhan ekonomi Markets dalam (Ismail, Alam, \& Hamid, 2017) menyebutkan "SMEs are the backbone of economic development, particularly in emerging".Dengan demikian semakin banyaknya jumlah Usaha Mikro Kecil Menengah (UMKM) di kawasan FTZ Kepualauan Riau diharapkan dapat meningkatkan pertumbuhan ekonomi.

Usaha mikro kecil dan menengah merupakan pemain utama dalam kegiatan ekonomi di Indonesia. Masa depan pembangunan terletak pada kemampuan usaha mikro kecil dan menengah untuk berkembang mandiri (Firmansyah, 2018).

Telaah pustaka tersebut sejalan dengan dengan penelitian yang dilakukan oleh (Firmansyah, 2018)yang mengungkapkan dalam penelitiannya bahwa "UMKM berpengaruh positif dan signifikan terhadap pertumbuhan ekonomi”. Berdasarkan argumen diatas maka penulis memuat hipotesis sementara sebagai berikut :

$\mathrm{H}_{2}$ : UMKM berpengaruh secara positif dan signifikan terhadap Pertumbuhan Ekonomi/PDRB.

\section{PMA}

Berdasarkan Undang-Undang Republik Indonesia Nomor 25 Tahun 2007 dalam Pasal 1 Ayat 9 Tentang Penanaman Modal, penanaman modal asing adalah kegiatan menanam modal untuk melakukan usaha di wilayah negara Republik Indonesia yang dilakukan oleh penanam modal asing, baik yang menggunakan modal asing sepenuhnya maupun yang berpatungan dengan penanam modal dalam negeri (Rizky, Agustin, \& Mukhlis, 2016). Dalam perusahaan Investasi merupakan pengeluaran dan pengorbanan aset secara keseluruhan yang mencakup pengeluaran untuk membeli bahan baku/mentah, mesin dan perlatan pabrik serta semua peralatan modal lain yang di dimanfaatkan dalam proses produksi sehingga menghasilkan pendapatan. (Momongan, 3013). Dalam laju pertumbuhan ekonomi Investasi adalah kata kunci penentu, karena akan mendorong kenaikan output secara produksi signifikan, sehinga otomatis akan meningkatkan permintaan input, uang pada akhirnya diharapkan dapat meningkatkan kesempatan kerja dan kesejahteraan masyarakat. (Makmun \& Yasin dalam (Momongan, 3013). Elemen utama dalam perkembangan industry di Indonesia salah satunya adalah dengan adanya Penanaman Modal Asing (PMA) (Hodijah, 2015).

Penelitian terdahulu yang dilakukan oleh (Momongan, 3013) yang menyatakan bahwa "PMA berpengaruh positif dan signifikan terhadap perkembangan PDRB”. Berdasarkan argumen dan hasil penelitian terdahulu maka peneliti dapat mengambil hipotesis semntara sebagai berikut :

$\mathrm{H}_{3}$ : Penanaman Modal Asing (PMA) berpengaruh positif dan signifikan terhadap Pertumbuhan Ekonomi/PDRB.

4. Ekspor

Ekspor merupakan aktivitas atau kegiatan penjualan barang ke luar negeri (wilayah) dengan memanfaatkan sistem pembayaran, kualitas, kuantitas dan syarat penjualan lainnya yang mana sistemnya telah disetujui oleh pihak eksportir maupun pihak importir negara yang dituju. ekspor merupakan salah satu mesin pendorong pertumbuhan ekonomi (Ginting, 2017). Kajian yang 
dilakukan oleh Salvator dalam penelitian Ginting menunjukkan bahwa ekspor merupakan salah satu faktor utama bagi negara-negara berkembang dalam meningkatkan pertumbuhan ekonomi. Semakin meningkatnya ekspor serta investasi yang dilakukan dalam sebuah negara yang sedang berkembang dapat mendorong output dan pertumbuhan ekonomi. Ekspor merupakan salah satu faktor terjadinya peningkatan salah satu pendorong utama dalam pertumbuhan ekonomi suatu negara (Ginting, 2017). Kegiatan ekspor negara merupakan akumulasi yang dilakukan oleh setiap daerah. Dengan adanya ekspor akan memperbaiki pertumbuhan ekomnomi di daerah. Hal ini sejalan dengan penelitian yang dilakukan oleh (M. Hidayat, Lapeti, \& Nobel, 2011)yang menyatakan bahwa ekspor berhubungan secara positif terhadap pertumbuhan ekonomi. Berdasarkan argumen dan hasil penelitian terdahulu maka peneliti dapat menarik hipotesis 1 sebagai berikut :

$\mathrm{H}_{4}$ : Ekspor berpengaruh positif dan signifikan terhadap Pertumbuhan Ekonomi/ PDRB.

\section{Inflasi}

Inflasi merupakan naiknya harga barang atau jasa secara umum yang disebabkan tingginya akan konsumsi masyarakat dan mempengaruhi pertumbuhan ekonomi karena inflasi sebagai stabilitas ekonomi dalam suatu wilayah. Menurut (Sukirno, 2002) inflasi disebabkan dua hal yaitu Inflasi tarikan permintaan inflasi desakan biaya, yaitu Inflasi yang umumnya terjadi pada masa perekonomian saat berkembang dengan pesat. Kesempatan kerja yang tinggi menciptakan tingkat pendapatan yang tinggi dan selanjutnya menimbulkan pengeluaran yang melebihi kemampuan ekonomi mengeluarkan barang dan jasa. Sedangkan Inflasi desakan biaya, yaitu Inflasi yang terjadi pada saat perekonomian berkembang dengan pesat serta tingkat pengangguran sangat rendah dan ditambah dengan langkanya produksi dan atau juga karena langkanya distribusi. Penelitian terdahulu yang dilakukan oleh (Surabaya \& Ekonomi, 2012) menununjukkan bahwa inflasi berpengaruh negatif dan signfikan terhadap pertumbuhan ekonomi di Indonesia. Berdasarkan teori dan penelitian terdahulu maka penulis dapat mengambil hipotesis sebagai berikut:

$\mathrm{H}_{5}$ : Inflasi inflasi berpengaruh negatif dan signfikan terhadap pertumbuhan ekonomi/PDRB.

\section{Pertumbuhan Ekonomi}

Pertumbuhan ekonomi adalah suatu kondisi yang terjadi karena adanya perkembangan GNP potensial yang mencerminkan adanya pertumbuhan output perkapita dan meningkatnya standar hidup di masyarakat. (dalam Kalsum, tanpa tahun). Pada umumnya, pertumbuhan ekonomi merupakan kenaikan pengeluaran agregat atas konsumsi barang dan jasa yang dihasilkan oleh adanya kegiatan atau aktifitas perekonomian atau Produk Domestik Bruto (PDB). Ukuran lazim yang digunakan untuk melihat pertumbuhan atau peningkatan ekonomi secara nasional adalah PDB sedangkan untuk mengukur suatu pertumbuhan ekonomi di suatu daerah baik provinsi ataupun kabupaten/kota adalah dengan melihat Produk Domestik Regional Bruto (PDRB).

Berdasarkan argumen dan telaah pustaka diatas maka penelitian tersebut dapat digambarkan dalam kerangka berfikir berikut ini: 


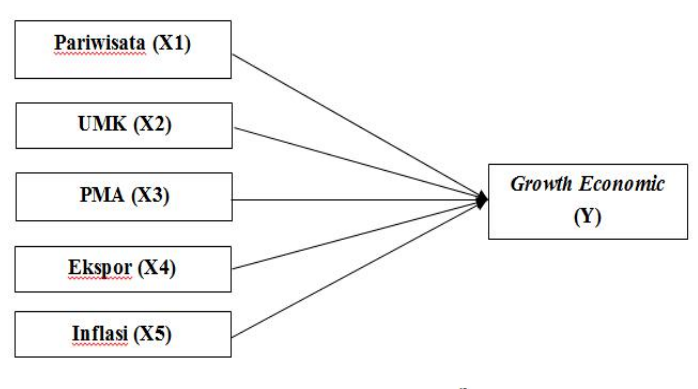

Gambar 1. Kerangka berfikir

Metode Penelitian

Desain Penelitian
Desain penelitian yang digunakan adalah jenis desain penelitian korelasional. Tujuan penelitian korelasional adalah untuk mendeteksi sejauh mana variai-variasi pada suatu faktor berkaitan dengan variasivariasi pada satu atau lebih pada faktor lain berdasarkan koefisien korelasi, Suryabrata dalam (A. Hidayat, 2012).

\section{Variabel Penelitian dan definisi operasional}

Variabel penelitian dan definisi operasional dapat dilihat pada tabel 2 berikut ini:

Tabel 2 variabel penelitiandan definisi operasional

\begin{tabular}{ll}
\hline Variabel Penelitian & Definisi Operasional \\
\hline PDRB/Pertumbuhan & PDRB/ Pertumbuhan ekonomi merupakan ukuran \\
Ekonomi & kemajuan ekonomi dalam suatu daerah \\
Pariwisata & Jumlah kunjungan warga negara asing yang dapat \\
meningkatkan pertumbuhan ekonomi \\
UMKM & UMKM penggerak roda perekonomian langsung \\
& masyarakat yang dapat meningkatkan pertumbuhan \\
& ekonomi melalui lapangan pekerjaan. \\
PMA & Penggerak tumbuhnya investasi yang meningkatkan \\
& sektor ekspor serta lapangan pekerja bagi masyarakat \\
& setempat. \\
Ukuran barang yang dihasilkan di dalam suatu wilayah \\
melalui penjualan barang secara internasional dengan \\
demikian berdampak terhadap pendapatan masyarakat \\
Beban yang dihadapi akibat naiknya harga yang dapat \\
menghalangi pertumbuhan ekonomi. \\
Inflasi
\end{tabular}

\section{Populasi dan Sampel}

Populasi yang digunakan dalam penelitian adalah populasi tidak terbatas, populasi tidak terbatas yaitu sumber datanya tak dapat ditentukan batas-batasnya sehingga relatif tidak dapat dinyatakan dalam bentu, (Bintoro, 2012). Oleh sebab itu sampel tidak dapat ditentukan. Pengumpulan data dengan cara mendokumentasikan data yang telah tersedia pada setiap daerah penelitian selama 5 tahun terakhir.

Jenis dan Metode Pengumpulan Data
Data yang digunakan untuk penelitian ini merupakan data sekunder kuantitatif dengan metode observasi (pengamatan) yang diperoleh dengan cara mendokumentasikan data dari sumber yang telah ada, yakni dengan melakukan pencatatan serta pengkopian atas data-data sekunder data yang diperoleh dari Dinas Pariwisata, Dinas Pemberdayaan Masyarakat, Pasar Koperasi dan Usaha Kecil, Menengah Kab/Kota kawasan FTZ Kepualaun Riau, Badan Koordinasi Penanaman Modal Badan Pengusahaan 
(BP) Batam, Badan Pusat Statistik (BPS) Kab/Kota kawasan FTZ Kepualaun Riau. Data yang diperoleh dalam penelitian ini data jumlah wisatawan asing, jumlah UMKM, jumlah PMA, Jumlah Ekspor dan data inflasi. Data-data tersebut akan diperoleh setiap bulannya selama 5 tahun yaitu dari tahun Januari 2014 Desember 2018. Jika data yang diperoleh tidak dapat setiap bulannya maka akan dilakukan interpolasi data menggunakan SPSS. Data yang diperoleh selanjutnya dilakukan analisis dan diolah menggunakan bantuan SPSS dan diambil kesimpulan serta saran yang diberikan kepada pemerintah khususnya Kab/Kota di Kepri yang mendapat fasilitas FTZ. Alur dalam penelitian ini dapat dilihat dengan mudah melalui chart dibawah ini:

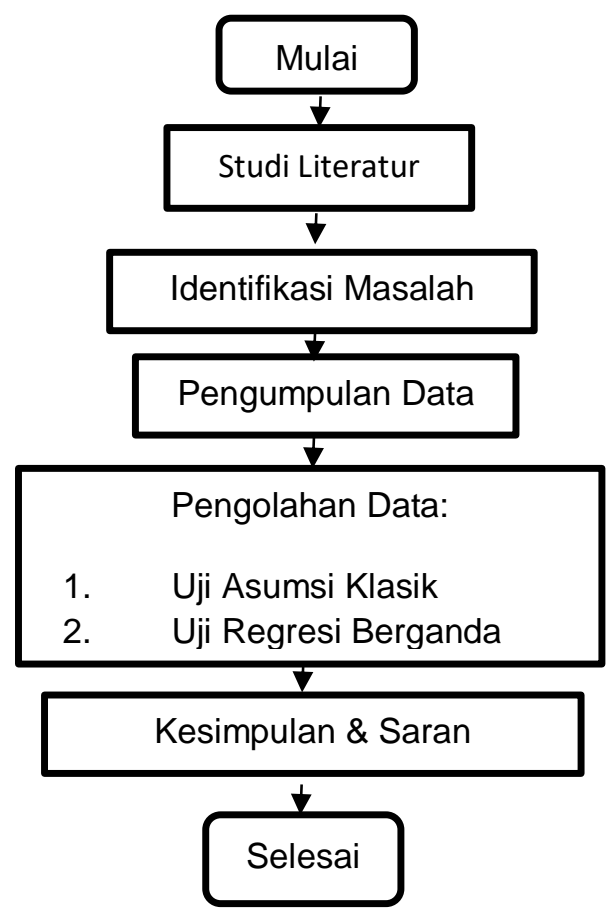

Gambar.2 Flow Chart Metode Penelitian

\section{Metode analisis}

Metode analisis yang digunakan yaitu menggunakan uji asumsi klasik dan uji persamaan regresi berganda.

\section{HASIL DAN PEMBAHASAN}

\section{Asumsi Klasik}

\section{Uji Normalitas}

\section{Tabel 1. Uji Normalitas \\ One-Sample Kolmogorov-Smirnov Test}

Unstandardized

Residual

\begin{tabular}{|c|c|c|}
\hline $\mathrm{N}$ & & 60 \\
\hline \multirow[t]{2}{*}{ Normal Parameters ${ }^{\mathrm{a}, \mathrm{b}}$} & Mean & .000 \\
\hline & Std. Deviation & 1.85 \\
\hline \multirow{3}{*}{$\begin{array}{l}\text { Most } \\
\text { Differences }\end{array}$} & eAbsolute & .125 \\
\hline & Positive & .055 \\
\hline & Negative & -.12 \\
\hline
\end{tabular}

Test Statistic .125

Asymp. Sig. (2-tailed) $.020^{\circ}$

a. Test distribution is Normal.

b. Calculated from data.

c. Lilliefors Significance Correction.

Dari output uji normalitas nilai signifikansi sebesar 0,20 lebih besar dari 0,05 sehingga dapat dikatakan dengan tegas bahwa variabel dependen telah berdistribusi secara normal.

\section{Uji Multikolinearitas}

Uji Multikolinearitas digunakan untuk memastikan apakah dalam penelitian ada dan atau tidaknya suatu korelasi antar variabel independennya maka dilakukan dua pengujian yaitu menggunakan motode TOL (Tolerance) dan VIF (Variance Inflation Factor). Variabel dapat dikatakan tidak mengalami suatu hal multikolinearitas apabila nilai Tolerancenya $\geq 0,10$ dan nilai $\mathrm{VIF} \leq 10$. Hasil uji multikoliniearitas dapat di lihat pada tabel berikut ini: 


\begin{tabular}{|c|c|c|c|c|}
\hline \multicolumn{5}{|c|}{ Tabel 2. Uji Multikolinearitas } \\
\hline & \multirow[b]{2}{*}{ Model } & \multicolumn{3}{|c|}{ Collinearity Statistics } \\
\hline & & Tolerance & VIF & $\mathrm{D}$ \\
\hline \multirow[t]{5}{*}{1} & PARIWIS & .269 & 3.718 & $\mathrm{~S}$ \\
\hline & UMKM & .318 & 3.140 & \\
\hline & PMA & .891 & 1.122 & \\
\hline & EKSPOR & 960 & 1.041 & \\
\hline & INFLASI & .809 & 1.237 & \\
\hline
\end{tabular}

a. Dependent Variable: PDRB

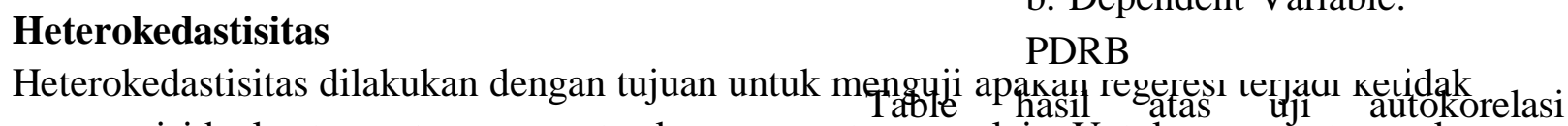
samaan risidual antara satu pengamatan ke pengamatan yang lain. Untuk pengamatan maka menyarakan bahwa terapat nilar Durbindigunakan grafik scaterplot di bawah ini :

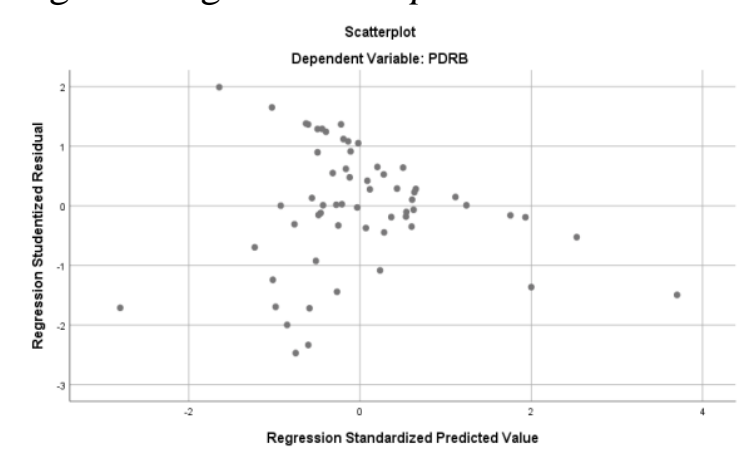

\section{Gambar 2. Grafik Scatteplot}

Berdasarkan hasil output grafik diatas menunjukkan bahwa semua titik-titik menyebar dan tidak membentuk suatu pola atau tidak teratur sehingga dapat dikatakan bahwa tidak terdapat heterokedastisitas.

\section{Uji Autokorelasi}

Uji autokorelasi digunakan dalam penelitian untuk menguji apakah dalam model regresi linear ada korelasi yang terjadi antara kesalahan pengganggu pada periode $\mathrm{t}$ dengan kesalahan pada periode $\mathrm{t}$ 1 sebelumnya, untuk mendeteksi ada atau tidaknya terjadi oautokorelasi yaitu dengan menggunakan deteksi sebagi berikut:

2. Apabila d lebih besar (>) dU maka tidak tidak terdapat autokorelasi

3. Apabila dL lebih kecil $(<)$ d dan lebih kecil dU maka pengujian terjadi hal keraguan/tidak menyakinkan sehingga tidak ada kesimpulan yang terjadi.

Data dari analisa dengan menggunakan SPSS adalah sebagai berikut : Model Summary ${ }^{b}$

\begin{tabular}{ll}
\hline \multicolumn{1}{c}{$\begin{array}{l}\text { Durbin- } \\
\text { Model }\end{array}$} & Watson \\
\hline $1 \quad 2.173$ \\
\hline $\begin{array}{l}\text { b. Dependent Variable: } \\
\text { PDRB }\end{array}$
\end{tabular}

Tabel 3. Uji Autokorelasi

Watson sebesar 2,173 sedangkan hasil nilai tabel signifikansi 5\% dengan $\mathrm{n}=60$ dan jumlah $\mathrm{k}=5 \mathrm{dU}=1,3719$ dan $\mathrm{dL}=1,8082$ artinya pada tabel ini $d>d U$ atau 2,173> 1,3719 sehingga dapat disimpulkan bahwa tidak terjadi hal autokorelasi.

\section{Uji Hipotesis Penelitian (persamaan Regresi Berganda)}

1. Koefisien Determinasi

Koefisien diterminasi (Adjusted $R^{2}$ ) dimanfaatkan dalam penelitian untuk mengukur sejauh mana kemampuan model dalam menerangkan variasi setiap variabel dependen yang digunakan. Nilai Adjusted $R^{2}$ yang mendekati mendandakan bahwa setiap variable independent memberikan hampir seluruh informasi yang dibutuhkan untuk memprediksi setiap variasi antar variabel dependen.

Menurut (Sugiyono, 2009) pedoman dalam memberikan interprestasi koefisien korelasi adalah sebagai berikut:
$0,00-0,25=$ sangat rendah
$0,25-0,50=$ rendah
$0,50-0,75=$ sedang
$0,75-0,99=$ kuat
$0,99-1,00=$ sangat kuat

Hasil atas uji koefisien determinasi yang dilakukan (Adjusted $\mathrm{R}^{2}$ ) bisa dilihat dari table berikut ini:

Tabel 4. Koefisien Diterminasi 
yaitu 2,39 dimana $F_{\text {tabel }}$ dihitung dengan menggunakan ketentuan tingkat signifikansi sebesar 5\%, dengan $\mathrm{dF}=\mathrm{n}-\mathrm{k}-1$ a. Predictors:, INFLASI, UMKM, EKSPOR, PNF $\$$, $0-5-1=54)$, sehingga didapat nilai $F_{\text {tabel }}$ PARIWISATA

b. Dependent Variable: PDRB

Berdasarkan tabel output nilai $\mathrm{R}$ (koefisien) sebesar 0,504 yang dapat menunjukkan bahwa terjadi hubungan yang sedang antar variabel, dengan ( $R$ square) sebesar 0,254 atau $25,4 \%$ masuk dalam kategori rendah. Nilai ini menunjukkan variabel Pariwisata, UMKM, dan inflasi mampu menjelaskan variabel Pertumbuhan Ekonomi/PDRB sebesar 25,4\%. Sedangkan sisanya dipengaruhi oleh variabel lain yang tidak dibahas dalam penelitian ini.

a. Uji F (Uji Secara Simultan)

Pengujian secara simultan (Uji F) yang dilakukan dapat dilihat dalam table berikut ini :

Tabel 5 Uji Simultan (F) ANOVA $^{a}$

\begin{tabular}{llrl}
\hline \multicolumn{2}{l|}{ Model } & F & Sig \\
\hline 1 & Regression & 3.67 & $.006^{\mathrm{b}}$ \\
& &
\end{tabular}

Residual

Total

a. Dependent Variable: PDRB

Yang menjadi pedoman untuk mengujihipotesis adalah uji hipotesis dalam uji $\mathrm{F}$ adalah:

1. Apabila nila sig lebih kecil $(<) 0,05$, maka hipotesis dapat diterima.

2. Apabila nilai sig lebih besar (>) 0,05 , maka terjadi penolakan atas hipotesi.

Dapat dilihat dalam tabel bahwa diperoleh nilai $\mathrm{F}_{\text {hitung }}$ adalah 3,678 dengan tingkat signifikansi 0,006. Dengan penggunaan siknifikansi $(\alpha) \quad 5 \%$. Berdasarkan tabel yang diperoleh diatas sebesar 0,006 $<0,05$, hal ini menunjukkan bahwa secara simultan variabel Pariwisata, UMKM Ekspor, PMA dan inflasi berpengaruh terhadap Pertumbuhan Ekonomi/PDRB. Hasil analisis ini diperkuat dengan membandingkan antara $F_{\text {hitung }}$ 3,678 yang jauh lebih besar dari $F_{\text {tabel }}$ sebesar 2,39 maka $F_{\text {hitung }}>F_{\text {tabel }}$ atau 3,678 > 2,39 sehingga dapat dismpulkan bahwa secara simultan semua varibel independent berpengaruh positif dan signifikan.

b. Uji t (Uji Secara Parsial)

Uji parsial (Uji t) pada dasarnya menunjukkan seberapa jauh satu variabel independen secara individual atau parsial dapat menerangkan variasi variabel dependen. Metode dalam penentuan t tabel menggunakan ketentuan tingkat signifikansi $5 \%$, dengan $\mathrm{df}=n-k-1$ (pada penelitian ini $\mathrm{df}=60-5-1=54)$, sehingga didapat nilai t tabel sebesar 1,67356. Hasil uji t dapat dilihat pada tabel berikut :

\section{Tabel 6. Uji T}

Coefficients $^{\mathrm{a}}$

\begin{tabular}{lllr} 
Model & & $\mathrm{T}$ & \multicolumn{1}{l}{ Sig. } \\
\hline 1 & (Constant) & -.331 & .742 \\
& PARIWISA & -3.503 & .001 \\
& TA & & \\
& UMKM & 2.481 & .016 \\
& PMA & 1.535 & .131 \\
& EKSPOR & 1.803 & .047 \\
& INFLASI & .439 & .662 \\
\hline
\end{tabular}

a. Dependent Variable: PDRB

Berdasarkan tabel output regresi tersebut dapat dijelaskan sebagai berikut:

1. Nilai $t_{\text {hitung }}(-3,503)<t_{\text {tabel }} \quad(1,67356)$ dengan nilai signifikan $(0,001)<(0,05)$, maka variabel Pariwisata/Wisman berpengaruh negatif terhadap Pertumbuhan Ekonomi/PDRB.

2. Nilai thitung $(2,841)>$ tabel $(1,67356)$ dengan nilai signifikan $(0,016)<(0,05)$, maka variabel UMKM berpengaruh positif terhadap pertumbuhan ekonomi/PDRB.

3. Nilai $t_{\text {hitung }}(1,535)<t_{\text {tabel }}(1,67356)$ dan nilai signifikan $(0,131)>(0.05)$, maka variabel PMA tidak berpengaruh terhadap Pertumbuhan Ekonomi/ PDRB.

4. Nilai $t_{\text {hitung }}(1,803)>t_{\text {tabel }}(1,67356)$ dan nilai signifikan $(0,047)<(0,05)$, maka 
variabel Ekspor berpengaruh terhadap Pertumbuhan Ekonomi/PDRB.

Nilai $t_{\text {hitung }}(0,439)<t_{\text {tabel }}(1,67356)$ dan nilai signifikan $(0,662)>(0,05)$, maka variabel Inflasi tidak berpengaruh terhadap Pertumbuhan Ekonomi/PDRB.

\section{Pembahasan Hasil Penelitian}

Berdasarkan hasil pengujian hipotesis maka dapat dibuat pembahasan sebagai berikut :

1. Pengaruh terhadap Ekonomi/PDRB.

Pariwisata/Wisman Pertumbuhan

Hasil pengujian hipotesis bahwa pariwisata/wisman tidak berpengaruh positif dan signifikan terhadap pertumbuhan ekonomi/PDRB. Hal ini dapat dilihat $t_{\text {hitung }}(-3,503)<t_{\text {tabel }}$ $(1,67356)$ atau dengan kata lain $\mathrm{H}_{1}$ ditolak.

Hal ini sejalan dengan teori yang dikemukakan oleh (Nizar, 2015) yang menjadikan sektor pariwisata membawa hal negatif terhadap negara dan daerah tujuan wisatawan asing adalah:

a. Terjadinya leakages impor dan ekspor, penurunan pendapatan pekerja dan penerimaan bisnis lokal. Leakages impor merupakan kebutuhan wiatawan asing yang yang tidak dapat dipenuhi oleh daerah tujuan seperti makanan peralatan dan lain sebagainya yang sesuai dengan standar pariwisata internasional. Leakages ekspor adalah keluarnya keuntungan atau penghasilan yang diperoleh di daerah tujuan ke luar negeri yang mana dana atas investasi tersebut diperoleh dari asing. Para investor asing tersebut melakukan transfer atau pengiriman ke luar daerah.

b. Adanya pelayanan terhadap turis secara inklusif sehingga terjadi adanya batasan manfaat oleh masyarakat.

\section{Pengaruh UMKM terhadap Pertumbuhan Ekonomi/PDRB.}

Hasil pengujian hipotesis secara parsial menunjukkan bahwa ada pengaruh secara positif antara UMKM terhadap pertumbuhan ekonomi/PDRB. Hal ini dapat dilihat dengan hasil nilai thitung $(2,841)>t_{\text {tabel }}(1,67356)$ dengan kata lain $\mathrm{H}_{2}$ diterima.

Dengan kata lain adanya pertumbuhan UMKM maka akan menyerap tenaga kerja yang mana pendapatan masyarakat akan mengalami peningkatan sehingga akan berdampak baik atau positif terhadap pertumbuhan ekonomi.

\section{Pengaruh Penanaman Modal Asing} (PMA) terhadap Pertumbuhan Ekonomi/PDRB.

Hasil pengujian yang dilakukan atas variabel PMA terhadap Pertumbuhan Ekonomoni/PDRB menunjukkan bahwa tidak ada pengaruh. Hal ini dapat dilihat dengan nilai $t_{\text {hitung }}(1,535)<t_{\text {tabel }}$ $(1,67356)$ dengan kata lain $\mathrm{H}_{3}$ ditolak.

Di Kepri sendiri khususnya wilayah FTZ para investor asing belum begitu tertarik untuk berinvestasi. Seperti yang termuat dalam berita harian koran dengan judul alasan investor asing enggan berinvestasi di bintan salahsatunya disebabkan karena terkendala lahan rumitnya administrasi perizinan ditambah lagi PMA yang sudah ada mengalami gulung tikar dan lain sebagainya.

\section{Pengaruh Ekspor terhadap} Pertumbuhan Ekonomi/ PDRB.

Hasil pengujian hipotesis secara parsial antara variabel ekspor terhadap pertumbuhan ekonomi/PDRB menunjukkan bahwa terdapat hubungan 
tidak berpengaruh positif dan signifikan

secara berpengaruh. Hal ini dapat dilihat dengan nilai Nilai thitung $(1,803)>$ $t_{\text {tabel }}(1,67356)$ dengan kata lain $\mathrm{H}_{4}$ diterima.

Dengan tingginya ekspor maka akan terbukanya peluang usaha dan penyerapan tenaga kerja sehingga akan memiliki pengaruh positif terhadap pertumbuhan ekonomi. Sebab tingginya ekspor disebabkan karena adanya permintaan barang ke luar negeri dan dalam proses produksi barang ekspor tersebut memerlukan tenaga kerja sehingga dengan demikian masyarakat setempat akan memiliki pekerjaan yang pada akhirnya akan meningkatkan pertumbuhan ekonomi masyarakat setempat.

\section{Pengaruh Inflasi terhadap pertumbuhan ekonomi/PDRB}

Hasil pengujian secara parsial yang dilakukan antara variabel inflasi terhadap pertumbuhan ekonomi/PDRB menunjukkan bahwa inflasi tidak berpengaruh negatif. Nilai thitung $(0,439)<t_{\text {tabel }}(1,67356)$ dengan kata lain $\mathrm{H}_{5}$ ditolak.

Hal ini dapat terjadi karena inflasi di kepulauan Riau masih masuk dalam kategori rendah sehingga inflasi tidak memiliki pengaruh terhadap pertumbuhan ekonomi/PDRB.

\section{Kesimpulan dan Saran}

Berdasarkan pengujian dan pembahasan yang telah dilakukan, maka dapat diambil beberapa kesimpulan dalam penelitian ini yaitu :

1. Secara simultan variabel sektor Pariwisata, UMKM dan inflasi berpengaruh terhadap pertumbuhan atau peningkatan ekonomi/PDRB di Kepulauan Riau.

2. Pengujian variabel secara parsial terhadap sektor Pariwisata/Wisman terhadap pertumbuhan ekonomi/PDRB di Kepualauan Riau (H1 ditolak).

3. UMKM berpengaruh positif dan signifikan terhadap pertumbuhan ekonomi/PDRB di Kepualauan Riau $\left(\mathrm{H}_{2}\right.$ diterima).

4. PMA tidak berpengaruh positif dan signifikan terhadap petumbuhan ekonomiPDRB di Kepualauan Riau (H3 ditolak).

5. Ekspor berpengaruh positif terhadap pertumbuhan ekonomi/PDRB di Kepulauan Riau (H4 diterima).

6. Inflasi tidak memiliki pengaruh negatif terhadap pertumbuhan ekonomi/PDRB di Kepulauan Riau (H5 ditolak).

7. Saran kepada pemerintah Kepri khususnya Kab/Kota yang mendapatkan fasilitas FTZ hendaknya meningkatkan objek wisata dan fasilitas yang lebih baik lagi agar wisatawan tidak memanfaatkan "leakages" dan dapat melayani wisatawan/wisatawan mancanegara secar "serba inklusif" karena dalam industri pariwisata-dimana segala sesuatu tersedia,sehingga para wisman tersebut dapat menikmati wisata yang sebenarnya dapat memberikan hal positif bagi pertumbuhan ekonomi.

\section{Ucapan Terimakasih}

Ucapan terimakasih yang sebesar-besarnya peneliti sampaikan kepada beberapa pihak yang mendukung penelitian ini yakni kepada:

1. DRPM DIKTI dengan kontrak No; 004/L10/AK.04/KONTRAK-

PENELITIAN/2019 yang mana Riset penulis sebagian dibiayai oleh Hibah PDP.

2. LPPM Univeritas Putera Batam yang telah menjadi penghubung antara peneliti dengan DIKTI dalam memperoleh hibah. 
3. Kepada pemerintah yang menjadi objek penelitian.

\section{Daftar Pustaka}

Bintoro, M. A. (2012). Jenis Jenis populasi dan sempel. Retrieved from http://bintorobagus.blogspot.com/201 2/09/jenis-jenis-populasi-dansempel.html

Firmansyah, A. I. (2018). Pengaruh pertumbuhan usaha mikro, kecil, dan menengah terhadap pertumbuhan ekonomi di tulungagung. (April).

Ginting, A. M. (2017). Analisis Pengaruh Ekspor Terhadap Pertumbuhan Ekonomi Indonesia. Buletin Ilmiah Litbang Perdagangan, 11(1), 1-20.

Hidayat, A. (2012). Penjelasan Desain Penelitian (Pengantar). Retrieved from

https://www.statistikian.com/2012/05/ desain-penelitian-pengantar.html

Hidayat, M., Lapeti, S., \& Nobel, A. (2011). ANALISIS FAKTOR-

FAKTOR YANG MEMPENGARUHI PERTUMBUHAN EKONOMI KOTA PEKANBARU. Jurnal Sosial Ekonomi Pembangunan, 2(4).

Hodijah, S. (2015). Analisis Penanaman Modal Asing Di Indonesia dan Pengaruhnya Terhadap Nilai Tukar Rupiah. Jurnal Pradigma Ekonomika. Ismail, M. D., Alam, S. S., \& Hamid, R. bt A. (2017). Trust, commitment, and competitive advantage in export performance of SMEs. Gadjah Mada International Journal of Business, 19(1), 1-18. https://doi.org/10.22146/gamaijb.226 80

Momongan, J. E. (3013). Investasi PMA dan PMDN Pengaruhnya Terhadap Perkembangan PDRB dan Penyerapan Tenaga Kerja Serta Penanggulangan Kemiskinan di Sulawesi Utara. Fakultas Ekonomi Dan Bisnis, Jurusan Ekonomi Pembangunan Universitas Sam Ratulangi Manado, 1(3 September), 530-539. Retrieved from https://ejournal.unsrat.ac.id/index.php /emba/article/view/2082/1655

Nizar, M. A. (2015). Tourism Effect On Economic Growth In Indonesia. MPRA Paper, (8225), 1-25. https://doi.org/10.1227/01.NEU.0000 349921.14519.2A

Rizky, R. L., Agustin, G., \& Mukhlis, I. (2016). Pengaruh Penanaman Modal Asing, Penanaman Modal Dalam Negeri Dan Belanja Modal Terhadap Pertumbuhan Ekonomi Provinsi Di Indonesia. Jesp, 8(1), 9-16.

Sugiyono. (2009). Metode Penelitian Kuantitatif, Kualitatif dan $R \& D$. Bandung: Alfabeta.

Sukirno, S. (2002). Teori Mikro Ekonomi. Jakarta: Rajawali Pess.

Surabaya, U. N., \& Ekonomi, P. (2012). Herman, Ardiansyah. Jurnal Pendidikan Ekonomi, Vol.5(No.3).

Undang-undang No 10 Tahun 2009 Tentang Kepariwisata.

Undang-undang No. 20 Tahun 2008 Tentang Usaha Mikro, Kecil dan Menengah.

Undang-undang No. 36 tahun 2000 tentang penetapan peraturan pemerintah pengganti

Undang-undang No. 1 tahun 2000 tentang kawasan perdagangan bebas dan pelabuhan bebas menjadi undang undang.

Undang-Undang Republik Indonesia Nomor 25 Tahun 2007 Tentang Penanaman Modal 